IEiB UKSW Warszawa

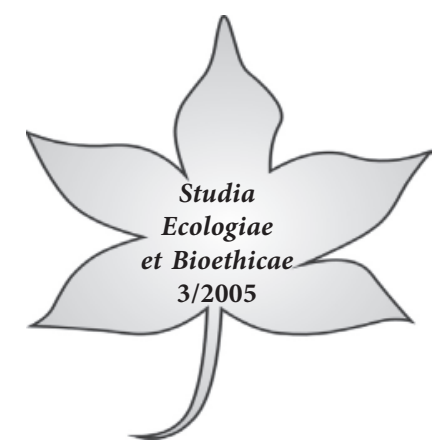

\title{
Historyczne i współczesne postawy wobec śmierci
}

Śmierć jest jednym z niewielu uniwersalnych doświadczeń człowieka. Chociaż ma ona wyjątkowo realny charakter, ponieważ nikt nie wątpi, że śmierć stanie się jego udziałem, to równocześnie istota tego wydarzenia okryta jest głęboką tajemnicą. I z tego też powodu umieranie poddawane było zróżnicowanym interpretacjom. Raz śmierć była przeżywana jako straszna i budząca przerażenie, to znowu jako upragniona i wzbudzająca ekstatyczny zachwyt. W większości europejskich i pozaeuropejskich kultur śmierć postrzegana była w kontekście religijnym, dlatego nie oznaczała ona całkowitego końca ludzkiej egzystencji, ale tylko przejście do innej formy życia ${ }^{1}$.

Od lat sześćdziesiątych ubiegłego wieku zauważamy w zachodnim kręgu kulturowym wzrost zainteresowania problematyką umierania i śmierci. Wskazują na to między innymi liczne publikacje, które ukazały się na ten temat w różnych $\mathrm{krajach}^{2}$. Powstała nawet nowa część bioetyki zwana tanatologią, która podejmuje temat śmierci w różnych aspektach, próbując opisać i uporządkować wiedzę $\mathrm{w}$ tym zakresie $\mathrm{e}^{3}$. Tanatologia bada śmierć $\mathrm{w}$ aspekcie medycznym, psychicznym,

1 Por. C. von Barloewen, Der Lange Schlaf. Der Tod als universelles Phänomen der Weltkulturen und Weltreligionen, w: Der Tod in den Weltkulturen und Weltreligionen, red. C. von Barloewen, Insel Verlag, 2000, 12.

2 Informator bibliograficzny: J.A. Miller \& M.J. ACri, Death. A Bibliographical Guide, London 1977, zawiera 3848 informacji bibliograficznych o publikacjach w różnych językach, najwięcej w j. angielskim. Przewodnik bibliograficzny Roberta Fultona: Heath. Grief and Bereavemenet II. A Bibliography 1975-1980, New York 1981, zawiera 2241 informacji o książkach i artykułach opublikowanych w USA w j. angielskim. Najwięcej wydano publikacji na temat śmierci w latach siedemdziesiątych XX wieku. W tych latach też 230 osób uzyskało stopień doktora na podstawie dysertacji na temat śmierci. Por. A. Siemianowski, Śmierć i perspektywa nadziei. Esej filozoficzny o ostatecznych sprawach człowieka, Gniezno 1992, 31.

3 Określenie „tanatologia” powstało $\mathrm{z}$ dwóch greckich słów thanatos (grecki bóg śmierci) i logos (słowo, nauka, dyscyplina). Tanatologia oznacza „badania nad umieraniem i śmiercią” albo „badania nad śmiercią, umieraniem, żałobą, zachowaniami niebezpiecznymi dla życia i samobójstwem". Por. I. SpIEgel-Rösing, Der thanatologische Kontext. Schwerpunkte, Entwicklungen, Defizite, w: I. Rösing, H. Petzold, Die Begleitung Sterbender. Theorie und Praxis der Thanatotherapie, Junfermann-Verlag, Paderborn $1992^{2} 10$. 
socjologicznym, ekonomicznym, teologicznym i filozoficznym jako zakończenie życiowego cyklu, starając się odpowiedzieć na pytania: jak ona przebiega i jak jest przeżywana, co wpływa na proces umierania i jego przeżywanie oraz jak członkowie określonej społeczności, np. grupy lub religii, podchodzą do umierania i śmierci zarówno wyobrażonej (obraz śmierci), śmierci cudzej i własnej oraz jej różnych form (samobójstwo, zabójstwo, wojna). Aspekt etyczny śmierci uwzględnia relację do umierających i określa warunki gwarantujące im tzw. godną śmierć. Można także mówić o etosie śmierci postrzegającym to zjawisko jako zadanie; ostatnie zadanie, które człowiek ma do wypełnienia.

Początek interdyscyplinarnego ujmowania tanatologii związany jest z książką H. Feifel'a The Meaning of the Death, McGraw-Hill, która równocześnie została uznana za publikację mającą wielki wpływ na rozpoczęcie współczesnych, poważnych studiów nad śmiercią. Książka ta zawiera między innymi informacje o tym, że grupą najbardziej obawiającą się śmierci są lekarze. Lęk lekarzy przed śmiercią powstrzymywał ich przed rozmowami na ten temat $\mathrm{z}$ innymi i wyzwalał także obawy przed śmiercią u ich pacjentów ${ }^{4}$.

Podstawowymi tematami uwzględnianymi w tanatologii są:

- Zagadnienia intrapersonalne, dotyczące procesów dokonujących się w pojedynczym człowieku w czasie umierania, przeżywanej żałoby po śmierci bliskiej osoby oraz sposobów interpretowania śmierci.

- Zagadnienia interpersonalne, związane przede wszystkim ze sposobem obchodzenia się z umierającymi przez osoby towarzyszące i personel medyczny.

- Zagadnienia instytucjonalne, podejmujące problematykę sposobów funkcjonowania szpitali, domów opieki, hospicjów oraz ich oddziaływania na umierających. W tej części omawiane są także obrzędy dotyczące śmierci i żałoby, nastawienia grupowe do śmierci oraz aspekty prawne śmierci (np. kara śmierci).

Wielka część tanatologii dotyczy aspektów medycznych, które opisują zjawisko biologicznego umierania, ale także uwzględniają procedury medyczne, które mogą ułatwić lub utrudnić przeżywanie ostatniego okresu życia.

\section{Biologiczno-medyczne aspekty śmierci}

W roku 1874 Akademia Medyczna w Paryżu ufundowała nagrodę za udokumentowane podanie cech zaistniałego zgonu człowieka ${ }^{5}$. Nagroda ta była związana z niedoskonałymi metodami diagnostycznymi, które uniemożliwiały precyzyjne określenie śmierci człowieka. Problem dotyczył zarówno samej definicji śmierci, jak też ustalenia jej klinicznych objawów. Z powodu tych trudno-

4 Por. H. Feifel, The Meaning of the Death, McGraw-Hill, New York 1959.

5 Por. G. Baust, Sterben und Tod. Medizinische Aspekte, Akademie Verlag 1988, 144. 
ści w przeszłości zdarzało się, że grzebano ludzi jeszcze żywych. Paryski lekarz z XVIII w., John Bruhier, ustalił 52 takie przypadki ${ }^{6}$. W literaturze można znaleźć opis niezwykłego zdarzenia, gdy chirurg Veselius dokonujący sekcji zwłok, po otwarciu klatki piersiowej dostrzegł bijące serce. Został on potem oskarżony o dokonanie morderstwa. Nic dziwnego, że pod wpływem informacji o takich wydarzeniach próbowano określić precyzyjne kryteria zgonu i definicję śmierci. Osiągnięciem w tym zakresie mógł się wykazać dr Icard, który wynalazł i wprowadził metodę wstrzykiwania do krwiobiegu pacjenta specjalnego barwnika. Jeżeli pacjent jeszcze żył, zmieniał się pod wpływem wprowadzonej substancji kolor jego ciała. W roku 1882 dr Icard otrzymał za ten rozstrzygający wątpliwości test specjalną nagrodę 7 .

Dzisiaj nie ma lęku przed pospiesznym uznaniem człowieka za zmarłego i pochowaniem go żywcem. W ostatnich latach narastają jednak dyskusje związane $\mathrm{z}$ określeniem momentu śmierci człowieka umożliwiającego pobieranie od niego narządów do transplantacji. W mediach wciąż na nowo podejmowane są wątpliwości dotyczące tzw. definicji śmierci mózgowej, której zarzuca się zbytnią arbitralność i podporządkowanie potrzebom medycyny transplantacyjnej.

Zwykle mówi się o trzech definicjach śmierci:

- Śmierć kliniczna, gdy ustaje spontaniczne oddychanie i bicie serca,

- Śmierć mózgowa, gdy ustają czynności mózgu,

- Śmierć komórkowa, gdy ustają czynności organizmu i następuje degeneracja organów'.

Każda definicja śmierci musi uwzględniać trzy elementy:

1) Nieodwracalność. Polega ona na tym, że utraconych funkcji organicznych nie można już przywrócić. Warunek ten jest ogromnie ważny, ponieważ uniemożliwia przedwczesne wykorzystywanie zjawiska śmierci.

2) Selektywność. Śmierć oznacza nieodwracalny zanik funkcji całego organizmu. W praktyce jednak stwierdzenie tego stanu jest niemożliwe, ponieważ musiałby wcześniej nastąpić rozkład całego ciała. Dlatego za wystarczające kryterium zgonu przyjmuje się wybrane objawy śmierci, które jednak wskazują na obumarcie całego organizmu.

3) Całościowość. Definicja śmierci nie może koncentrować się wyłącznie na fizycznych lub psychicznych funkcjach organizmu. Powinno się uwzględniać takie kryterium śmierci, które dawałoby pewność, że cały człowiek nieodwracalnie przestał istnieć.

\footnotetext{
6 Por. A. Ostrowska, Śmierć w doświadczeniu jednostki społeczeństwa, Wydawnictwo IFIS PAN, Warszawa 1997, 62.

Por. tamże.

8 Por. Ozon, nr 32 24-30 listopada 2005, 30nn.

9 Por. A. Ostrowska, Śmierć w doświadczeniu jednostki społeczeństwa, dz. cyt., 63
} 
W roku 1968 powołano w Harward Medical School Komisję Nadzwyczajną (Ad Hoc Commitee), która zaproponowała społeczności medycznej tzw. zespół śmierci mózgowej. Obecnie mówi się o śmierci pnia mózgu.

Kościół katolicki przyjął również śmierć mózgu jako kryterium śmierci człowieka. Karta Pracowników Służby Zdrowia mówi: „Aby osoba była uważana za zmarłą jest wystarczające stwierdzenie śmierci mózgowej dawcy, która polega na nieodwracalnym ustaniu wszystkich funkcji mózgu. Gdy całkowita śmierć mózgu jest stwierdzona z pewnością, to znaczy po odpowiedniej weryfikacji, można przystąpić do pobrania narządów, jak również do sztucznego zastąpienia funkcji organizmu, by zachować przy życiu funkcje narządów ze względu na przeszczep"10. Objawami śmierci mózgowej są: zapis EEG (encefalografu) oraz 1) brak refleksu bólowego, 2) brak odruchu wymiotnego i kaszlowego, 3) brak odruchu źrenic oka, 4) brak odruchu rogówkowego oka, 5) brak odruchu termicznego, 6) brak odruchu oczno-mózgowego (przy gwałtownym obrocie głowy człowieka gałka oczna się nie rusza) $)^{11}$.

Śmierć mózgowa wraz z towarzyszącymi jej symptomami jest dowodem nieodwracalnego zaniku funkcji życiowych. Mimo to w ostatnim okresie pojawiają się wątpliwości dotyczące tego kryterium. Najpierw podnosi się kwestię woluntarystycznego określenia granicy życia związanego ze śmiercią mózgową, podczas gdy inne procesy życiowe jeszcze trwają. Czy można śmierć człowieka sprowadzać wyłącznie do obumarcia wyższych centrów systemu nerwowego ${ }^{12} \mathrm{Z}$ resztą nie pozostawiające wątpliwości stwierdzenie śmierci przy pomocy analizy zapisu encefalograficznego jest możliwe dopiero wtedy, gdy obserwacja następuje dwukrotnie w odległości czasowej sześciu godzin ${ }^{13}$. Niekiedy mówi się nawet o konieczności przeprowadzenia testu po 24 godzinach $^{14}$. Po takim okresie oczekiwania serce zmarłego nie nadaje się już do przeszczepu, podczas gdy inne organy przy zastosowaniu wymuszonych funkcji wegetatywnych mogą być jeszcze transplantowane.

10 Papieska Rada ds. Duszpasterstwa Służby Zdrowia, Karta Pracowników Służby Zdrowia, Watykan 1995, nr 87. W Polsce używa się od kilku lat zamiast określenia „śmierć mózgu” - „śmierć podstawy mózgu”. Por. dr med. Burak, Dyskusja wokół śmierci mózgowej, w: Etyczne aspekty transplantacji narządów. Materiały z sympozjum w Kamieniu Śląskim w dnia 15-16.04.1996, red. A. Marcol, Opole 1996, 54.

11 Por. E. Nagel, P. Sснмidt, Transplantation. Leben durch fremde Organe, Springer Verlag, Berlin-Heidelberg - New York 1996, 20-21.

12 Por. C. Golser, Dyskusja wokół śmierci mózgowej, w: Etyczne aspekty transplantacji narządów, dz. cyt., 39-55.

13 Por. Pontificio Consiglio „Cor Unum”, Alcune questioni etiche relative ai malati gravi e ai morenti (1981) w: Biologia, medicina ed etica. Testi del Magistero cattolico, red. P. Vespieren, Brescia 1990, 503.

14 Por. K. SzewCZyK, Lęk, nicość i respirator. Wzorce śmierci w nowożytnej cywilizacji Zachodu., w: Umierać bez lęku. Wstęp do bioetyki kulturowej, red. M. Gałuszka, K. Szewczyk, PWN, Warszawa-Łódź 1996, 77. 
W związku z tym niektórzy stawiają pytanie, czy w ogóle przeprowadzanie transplantacji serca jest etycznie dozwolone, skoro jego pobranie od dawcy może oznaczać faktyczne jego uśmiercenie ${ }^{15}$. Rodzi się również wątpliwość, czy pobieranie narząáów od zmarłego bezpośrednio po śmierci mózgowej nie jest związane z odczuwaniem przez niego bólu ${ }^{16}$.

Chociaż śmierć jest faktem, to jednak człowiek szuka dla niej interpretacji pozwalającej ją zrozumieć, a przynajmniej zintegrować z ogólną wizją życia ludzkiego. Dlatego tanatologia szuka filozoficznego i teologicznego wyjaśnienia śmierci.

\section{Sprzeczne postawy wobec śmierci we współczesnym świecie}

Umieranie i śmierć należą do tych zjawisk, które wywołują krańcowe reakcje i postawy. W historii znamy odległe w czasie przypadki skupienia uwagi pojedynczych osób i całych środowisk na ukierunkowaniu ludzkiego życia ku śmierci, co w konsekwencji prowadziło do negacji radości życia i przekonania o jego absurdalności. Równocześnie jednak znamy próby wypierania faktu śmierci ze świadomości indywidualnej i zbiorowej, wrogiego nastawienia do wszystkiego, co przypomina o ograniczoności ludzkiego życia (maskowanie cmentarzy, usuwanie czarnego koloru, wprowadzanie eufemizmów zastępujących terminy mówiące o umieraniu i śmierci). Postawy takie mogą być reakcją na zjawiska przeciwstawne, mogą też współegzystować ze sobą. Często noszą one znamię ideologii.

Na przełomie II i III tysiąclecia coraz częściej spotykamy się z próbami realistycznego podchodzenia do zjawiska umierania i śmierci. Autorzy o nastawieniu religijnym i świeckim podejmują ten temat jako przynależący do ludzkiego życia w sposób konieczny. Dostrzegają oni absurdalność unikania tematu śmierci, wypierania jej ze świadomości i zaprzeczania jej. Mówią o nowej kulturze umierania, która akceptuje nieodzowność końca życia jako ściśle przynależącą do ludzkiego losu. Podkreślają, że narodziny i śmierć są dwiema klamrami spinającymi każdą ludzką egzystencję.

\section{Historyczne postawy wobec śmierci}

Zjawisko śmierci jest trudne do systematycznego opisania, interpretacji, a tym bardziej do zrozumienia i akceptacji. Zadanie to może ułatwić spojrzenie historyczne na śmierć. Pozwoli ono z jednej strony zapoznać się, jak w przeszłości postrzegano śmierć, jak była ona przeżywana i interpretowana; $z$ drugiej zaś

15 Por. T. ŚLıpкo, Granice życia. Dylematy współczesnej bioetyki, Wydawnictwo WAM, Kraków 1994, 215-216.

16 Por. E. NAgel, P. Schmidt, Transplantation, dz. cyt., 23. 
strony pomoże uchwycić stałe elementy towarzyszące temu zjawisku i postawom wobec śmierci.

W roku 1978 historyk Philippe Ariès wydał monumentalne dzieło L'homme devant la mort (Człowiek wobec śmierci) ${ }^{17}$. Punktem wyjścia dla jego rozważań było założenie, że musi istnieć relacja pomiędzy postawą człowieka wobec śmierci a jego świadomością, czy indywidualnością. Ariès zauważył, że to indywidualne nastawienie do śmierci jest społecznie uwarunkowane. Jego zdaniem w historii da się zauważyć w odniesieniu człowieka do śmierci cztery trwałe elementy. Są nimi: 1) świadomość człowieka, 2) obrona społeczeństwa przeciwko dzikiej naturze, 3) wiara w życie pozagrobowe, 4) wiara w istnienie złego ducha ${ }^{18}$.

Inną próbę systematyzacji historycznych postaw wobec śmierci zawiera książka M. Vovelle’a, Śmierć w cywilizacji Zachodu ${ }^{19}$. Autor ten zna dorobek Ariès’a, a mimo to próbuje w inny sposób zorganizować materiał historyczny. M. Vovelle zwraca uwagę, że europejskie średniowiecze pozostaje pod głębokim wpływem chrześcijaństwa, dlatego różne postawy wobec śmierci mają związek z chrześcijańską antropologią i wiarą w życie pozagrobowe. Autor ten mówi co prawda o tzw. śmierci magicznej, czyli interpretacjach odwołujących się do przesądów, zabobonów, gestów o tajemnej sile, ale dotyczyły one niewielkich obszarów i pojawiały się głównie przed rokiem $1000^{20}$.

\section{a) Śmierć oswojona}

Ariès zaczyna swój przegląd historycznych postaw wobec śmierci modelem śmierci oswojonej lub poskromionej. Niesie on ze sobą przesłanie, że śmierć jest bliska, dobrze znana, nie przerażająca, ale raczej mało zauważalna. Nie stanowi ona, podobnie jak całe życie ,jakiegoś wyłącznie indywidualnego wydarzenia”. Dlatego też, podobnie jak inne zwrotne wydarzenia życiowe zaczyna się uroczystą ceremonią, która wzmacnia solidarność jednostki z jego szczepem i wspólnotą. Śmierć oznaczała szczególnie wtedy, gdy była wydarzeniem powtarzającym się, wyłom w systemie bezpieczeństwa, który społeczność ustanowiła dla zwalczania dzikiej natury ${ }^{21}$.

17 Por. Ph. Ariès, L'homme devant la mort, Editions du Seuil, Paris 1978. Polska wersja: por. tenże, Człowiek i śmierć, Warszawa 1989. Podstawą dalszych rozważąń będzie wersja niemiecka: Ph. Ariès, Geschichte des Todes, Deutscher Taschenbuch Verlag München 1999.

18 Por. tamże, 773n.

19 M. Vovelle, Śmierć w cywilizacji Zachodu. Od roku 1300 po współczesność, Wydawnictwo Słowo-Obraz-Terytoria, Gdańsk 2004.

20 Przykładem „śmierci magicznej“ może być przestroga: „Kto pranie w piątek wylewa, męża śmierci się spodziewa“. Por. tamże, 56n.

21 Por. U.H.J. Körtner, Bedenken, dass wir sterben müssen. Sterben und Tod in Theologie und medizinischer Ethik, Verlag C.H. Beck, München 1996, 15. 
Śmierć była także oswojona przez wiarę w życie pozagrobowe. Koniec życia doczesnego był oczywisty, nie utożsamiał się on jednak z unicestwieniem całkowitym człowieka, ale przenosił jego istnienie w inny wymiar i inne warunki, chociaż dokładanie nie były one sprecyzowane. Mimo takich sposobów oswajania śmierci, była ona zawsze postrzegana jako nieszczęście i tragiczne wydarzenie.

Francuski historyk Jean Delumeau mówi w tym kontekście o spoufaleniu się ze śmiercią ${ }^{22}$. Wynikało ono z jednej strony z postawy zwanej contemptus mundi - pogarda dla świata, ale przede wszystkim spowodowane było obawą przed grzechem i jego konsekwencją - potępieniem. Stałe obcowanie z myślą o nieuchronnej śmierci miało strzec przed uleganiem pokusom. Temu służyły sugestywne opowieści o przemijalności życia i jego kruchości. Literatura średniowieczna zawiera liczne przykłady tej konwencji. „Spójrzmy na ziemię: biedni ludziska, których na niej widzimy, z głową zwieszoną po dziennym trudzie... iluż, którzy pragną śmierci lub znoszą ją bez trwogi i zgryzoty? Człowiek, który kopie mój ogród, pogrzebał tego ranka swego ojca lub syna" (Michel de Montaigne (1533-92). W celu obrzydzenia życia z upodobaniem opowiadano o "gniciu trupa”, o rozkładaniu się ciała itd. „Po człowieku robak, po robaku smród i obrzydliwość" ${ }^{23}$. Ten akcent kładziony na „gnicie trupa”, który miał na celu doprowadzenie czytelnika do pogardy świata, był obecny w całym średniowieczu. Już Andrzej z Krety w VII wieku dawał radę człowiekowi zbliżającemu się do grobu: „Nie cofnij się... patrz prosto na ten niemiły widok... Zostań dość długo, byś poczuł wonie, które nie są wszak obce: to taki jest nasz zapach. Znieś po męsku smród dobywający się z tej zgnilizny i wyziewy z wydzielin. Trwaj dzielnie przy obrazie robaków i sączącej się zgniłej ropy, ty, któryś został powołany do tego, byś stał się pożywieniem żarłocznych robaków"24.

W latach 1347-1536 Europa była regularnie wyniszczana przez tzw. czarną śmierć ${ }^{25}$. Dżuma powracała średnio co 12 lat, a w niektórych regionach nawet częściej, uśmiercając niekiedy nawet $75 \%$ ludności ${ }^{26}$. Prawdopodobieństwo zarazy i częsta znajomość jej ofiar sprawiały, że śmierć stawała się bliska, tym bardziej, że postrzegana była często jako kara za popełnione grzechy. Śmierć stawała się codziennością. W roku 1591 rozporządzenie królewskie w Krakowie nakazywało, aby w przypadku zarazy dziesiętnicy obchodzili każdego dnia rano

22 Jean Delumeau, Grzech i strach. Poczucie winy w kulturze Zachodu XIII-XVIII w., Wydawnictwo PAX, Warszawa 1994, 51.

23 Tamże, 61.

24 Tamże.

25 Dżuma dymienicza (czarna śmierć) - najczęstsza postać dżumy; po wniknięciu zarazka pod skórę (2-5 dni po ukąszeniu przez pchłę) w obszarze węzłów chłonnych tworzą się bolesne, ropiejące guzy wielkości gęsiego jaja; przebiega z gorączką, złym stanem ogólnym, oraz w okresie preagonalnym z wybroczynami i krwawieniami na skórze. Por. Hexal. Podręczny Leksykon Medyczny, Wyd. Medyczne Urban \& Partner, Wrocław 1996, 155.

26 Por. M. Vovelle, Śmierć w cywilizacji Zachodu, dz. cyt., 110n. 
i wieczorem swoje rewiry, a gdy cyrulik rozpozna zarazę, należało zabezpieczyć okna i drzwi domu w taki sposób, aby nie można go było opuścić, dostarczając jednak żyjącym w nim ludziom potrzebną żywność ${ }^{27}$. „Czarna śmierć” w Krakowie w roku 1677 zabrała 21572 osoby $^{28}$.

Śmierć stawała się oswojona także z powodu szczęśliwego losu zmarłych, którzy osiągnęli „spokój Boży”. Śmierć oznaczała bowiem dla nich rodzaj wyzwolenia. Taka „dobra śmierć” nachodziła człowieka najczęściej w łóżku i była przez niego oczekiwana. Po świątobliwej śmierci zmarły powinien opiekować się żyjącymi, dlatego grzebano go w pobliżu kościoła. Ten sposób spoufalenia ze śmiercią był spowodowany chrześcijańskim modelem umierania ${ }^{29}$.

\section{b) Śmierć własna}

Drugi model historycznego stosunku do śmierci podkreśla wprawdzie powszechność tego wydarzenia, ale przenosi je na poszczególne jednostki. Model ten głosi: każdy człowiek, i ja też muszę umrzeć! Jeżeli świadomość indywidualnej śmierci nie była pielęgnowana powszechnie, ale tylko w niektórych kręgach elitarnych: rycerzy, zakonników, kanoników, to dlatego, że wymagała ona określonego poziomu umysłowej kultury. Indywidualnej świadomości zbliżającego się końca życia towarzyszyło przeświadczenie, że w godzinie śmierci trzeba zamknąć swoje życie i rozliczyć się z nim. Po śmierci ciała rozpoczynał się nowy okres egzystencji, na który człowiek nie miał bezpośredniego wpływu, mógł jednak zapewnić sobie lepszą przyszłość przez zamawianie Mszy św. i zakładanie pobożnych fundacji. Trwałej świadomości zbliżającego się końca życia towarzyszyło często wielkie umiłowanie życia doczesnego i jego radości. W stosunku do poprzedniego modelu uświadomiona „śmierć własna” kładła większy nacisk na życie pozagrobowe, ponieważ w odróżnieniu od życia doczesnego było ono pozbawione granic czasowych i utożsamiało się z głównym chrześcijańskim celem - zbawieniem. Pojawiły się też nowe obyczaje, które sprawiły, że śmierć została nieco przesłonięta tajemniczością (całun, katafalk, pomniki).

Zmiana ta zaczęła się już w XII wieku i związana byłą z nową stratyfikacją społeczną. Przynależność do różnych grup społecznych widoczna była w jakości obrzędów pogrzebowych, które zmarłemu przysługiwały. Wobec narastających tendencji do coraz bardziej wystawnych pochówków, obrzędy te próbowano ograniczać przez różne zakazy: zmniejszając liczbę dni trwania obrzędów pogrzebowych, ograniczając liczbę uczestników pogrzebu tylko do bliższych krewnych (np. do czwartego stopnia), czy wreszcie ograniczając wyrazy żalu.

\footnotetext{
27 Por. J. KraciK, Pokonać czarną śmierć. Staropolskie postawy wobec śmierci, Wydawnictwo m, Kraków 1991, 67.

28 Por. tamże, 98.

29 Por. M. Vovelle, Śmierć w cywilizacji Zachodu, dz. cyt., 84.
} 
W konsekwencji tych poczynań śmierć została oderwana od codzienności, otoczona natomiast była coraz bardziej uroczystymi rytuałami ${ }^{30}$.

Model śmierci własnej i poszukiwanie „dobrej śmierci”, gwarantującej szczęśliwe życie pozagrobowe dało początek nowemu gatunkowi literatury zwanej ars moriendi (sztuka umierania). Najbardziej znane dzieła tego nurtu to Admonitio morienti Anselma z Canterbury (1034-1109) i De arte moriendi Jana Gersona (1363-1429). Najwcześniejszym polskim utworem odpowiadającym tej konwencji jest pochodzący z XV wieku Dialog Mistrza Polikarpa ze Śmiercią. Autorzy należący do tego nurtu literatury pisali książki zawierające rady, wskazówki i zasady jak umierający powinien przygotować się do zbawiennej śmierci. Teksty te były pierwotnie pomyślane jako pomoc dla niedoświadczonego kapłana, który został wezwany do umierającego. Szybko jednak ich przeznaczenie uległo zmianie. Zostały one skierowane do wszystkich, którzy towarzyszą umierającym. W późniejszym okresie poradniki te jeszcze bardziej zmieniły treść i adresata. Zostały one skierowane do wszystkich żyjących, aby ich przygotować do „dobrej śmierci". Warunkiem takiej śmierci było dobre, moralne życie zgodnie z zasadą: „jakie życie taka śmierć”. Ars moriendi miała więc przede wszystkim wymiar religijny. Dobra śmierć była bowiem zapowiedzią religijnego zbawienia ${ }^{31}$. Literatura nurtu ars moriendi pełniła funkcję, którą dzisiaj nazwalibyśmy pedagogiką tanatologiczną. Oswajała ona z tematem śmierci i przygotowywała na jej przyjęcie.

\section{c) Śmierć zdziczała}

Model tzw. śmierci zdziczałej pojawia się na początku XVI wieku. Śmierć przeżywana i ukazywana w tym modelu jawi się jako długa i bliska, ponieważ towarzysząca człowiekowi przez całe życie. Paradoksalnie do takiego sposobu patrzenia na śmierć doprowadziła w sposób uboczny i niezamierzony praktykowana ars moriendi, która najpierw koncentrowała uwagę na pożądanych, dobrych sposobach umierania, aby następnie dojść do wniosku, że całe życie człowieka jest drogą prowadzącą do śmier$\mathrm{ci}^{32}$. Traktowanie egzystencji ludzkiej jako czasu przeznaczonego na przygotowanie dobrej śmierci przyczyniło się do tego, że sama śmierć zaczęła się jawić jako wydarzenie najbardziej dramatyczne w życiu, wydarzenie smutne, bo nieodwołalnie kończące indywidualną historię człowieka. Konsekwencją takiego postrzegania śmierci było pozbawienie jej religijnego i nadprzyrodzonego wymiaru. Rozważania i opisy umierania poprzedzonego chorobą, wyzwoliło tęsknotę za śmiercią nagłą, pozbawioną poprzedzających ją cierpień. Drugą konsekwencją postrzegania życia jako drogi do śmierci było przypisywanie coraz większej wartości życiu doczesnemu.

\footnotetext{
30 Por. M. Mischke, Der Umgang mit dem Tod. Vom Wandel in der abendländischen Geschichte, D. Reimer Verlag, Berlin 1996, 53.

31 Por. H.R. Kassel, Ars Moriendi. Eine Sterbekunst aus der Sorge um das ewige Heil, w: Ars Moriendi. Erwägungen zur Kunst des Sterbens, red. H. Wagner, Herder 1989, 15-44.

32 Por. Ph. ArIEs, Geschichte des Todes, dz. cyt., 385
} 
Stosunek ludzi późnego średniowiecza do życia jest wewnętrznie sprzeczny. Z jednej strony mocna świadomość nieodzowności śmierci i perspektywy życia pozagrobowego oraz możliwości potępienia, stąd tendencja do całkowitego wyrzekania się radości życia. $Z$ drugiej strony zauroczenie życiem doczesnym i chętne oddawanie się jego przyjemnościom. Ta druga opcja powoli brała górę i prowadziła do stopniowego zatarcia w świadomości indywidualnej i społecznej nieodzowności śmierci. U schyłku średniowiecza kończy się skupienie na śmierci, w centrum uwagi pojawia się natomiast barwne, bogate życie. Śmierć doznała potrójnego zaprzeczenia: na poziomie wierzeń i praktyk ludowych, na poziomie intelektualnej elity hołdującej ideałom renesansu i humanizmu, wreszcie przez reformację, która podjęła problem zbawienia w nowy sposób ${ }^{33}$.

\section{d) Śmierć ceremonialna}

Średniowieczne zainteresowanie śmiercią i praktyka ars moriendi uwarunkowane były w dużej mierze strachem przed piekłem. Sobór trydencki w roku 1563 ogłosił Dekret o czyśćcu, w którym przypomniał zakwestionowaną przez M. Lutra doktrynę o możliwości uzyskania po śmierci przez cierpienia własne oraz wstawiennictwo i modlitwy żyjących uwolnienia od kary za grzechy i uzyskania zbawienia ${ }^{34}$. Dokument ten odbił się szerokim echem w Europie katolickiej i wpłynął na zmianę ponurego nastroju kształtowanego wizją ognia piekielnego. Wiek XVII był wiekiem czyśćca ${ }^{35}$. Nie oznacza to jednak, że śmierć przestała być $\mathrm{w}$ centrum uwagi. Wręcz przeciwnie, sztuka $\mathrm{z}$ upodobaniem powracała do tematów funeralnych. Barokowe upodobanie do przesady, makabry, a nawet w pewnym sensie do sadyzmu odbijały się w myśleniu, przeżywaniu i wyrażaniu swoich uczuć o śmierci. Chociaż ulubionym motywem w sztuce był szkielet ludzki pozbawiony ciała, to sztuka ta była mniej agresywna, niż w poprzednich wiekach ${ }^{36}$.

Śmierć $\mathrm{w}$ baroku postrzegano jako zakończenie życia, dlatego powinna być ona godnie przeżywana. Służył do tego ceremoniał dworski, który z jednej strony podkreślał znaczenie śmierci, ale równocześnie przenosił sposób jej przeżywania na poziom rytualny, umowny, nierzeczywisty. Wbrew napomnieniom Kościoła katolickiego i nawoływaniom reformatorów protestanckich do prostoty, epoka baroku lubowała się w wystawnych, pełnych przepychu i teatralności pogrzebach.

33 Por. M. Vovelle, Śmierć w cywilizacji Zachodu, dz. cyt., 193.

34 Por. Dekret o czyśćcu, Breviarium fidei. Wybór doktrynalnych wypowiedzi Kościoła, Księgarnia św. Wojciecha, Poznań 1989, VIII, 117.

35 Jak wielkie było zainteresowanie problematyka czyśćca świadczy fakt, ze w latach 1580-1680 opublikowano 136 prac na ten temat. Por. M. Vovelle, Śmierć w cywilizacji Zachodu, dz. cyt., 303.

36 Por. tamże, 243. 


\section{d) Śmierć zakwestionowana}

W wieku XVIII nastąpiła zmiana w postrzeganiu i przeżywaniu śmierci. Zmianę tę wyraża jeden z bohaterów D. Diderota. Zapytany o życie po śmierci - odpowiada: „Ani wierzę, ani nie wierzę; nie myślę o nim”. Rozwój nauki i techniki, które niosło ze sobą oświecenie, prowadziły od połowy XVIII do laicyzacji kultury europejskiej, a to $\mathrm{z}$ kolei pociągało za sobą osłabienie wiary w piekło. Trzeba jednak zauważyć, że dla większości ludzi epoki oświecenia Bóg „nie umarł". Funkcjonując jako Najwyższa Istota albo Wielki Architekt, pozostawał najwyższą instancją. Podobnie niekwestionowana była nieśmiertelność duszy. Był to jednak Bóg daleki, w niewielkim stopniu interesujący się ludźmi, nie będący arbitrem dobra i zła. Osiągnięcia gospodarcze i naukowe, bogacenie się oraz intensywne życie umysłowe i towarzyskie absorbowały aktywność ludzi. Wiara w rozum ludzki i optymizm dotyczący przyszłości uwały myśli o przemijaniu. Uwaga ludzi koncentrowała się na sprawach materialnych i technicznych, co szczególnie widoczne było się w sporządzanych testamentach. Sprawy duchowe nie zajmowały w nich wiele miejscach, były najwyżej wzmiankowane. Głównym tematem ostatniej woli umierających były kwestie majątkowe. Śmierć powoli poddawana była racjonalizacji: strach przed przemijaniem i zgonem był rozpraszany jako przejaw przesądów i odwiecznych lęków. Zmarli traktowani też byli z mniejszym respektem; grzebani na cmentarzach poza obszarami miejscowości, byli traktowani jako skazańcy na umownym wygnaniu ${ }^{37}$. Odejście od społecznego rozumienia śmierci prowadziło również do uproszczenia żałoby. Zanikał żałobny teatr, który był elementem życia społecznego w poprzedniej epoce. Żałoba stawała się czymś prostszym, podobnie jak sama śmierć. Rodzaj pogrzebu wciąż jednak świadczył o pozycji umarłego i jego rodziny. Ponieważ śmierć uważana była za zjawisko negatywne, dlatego też, jeżeli nie można było jej uniknąć, powinna była przebiegać szybko i bezboleśnie.

Romantyzm pasjonujący się dziką naturą, z którą wcześniejsze wieki walczyły, teraz dostrzegał w wydarzeniu śmierci element piękna. Pojawiło się nawet pojęcie śmierci romantycznej ${ }^{j 8}$. Estetyzacja śmierci niosła ze sobą konsekwencję wyrwania jej z pod wpływu złego ducha i wyciszenia tematyki piekła. Pozbawienie śmierci i umarłych cech odrażających, uczyniło $\mathrm{z}$ umierania wydarzenie towarzyskie. Akcentowano możliwość spotkania w życiu pozagrobowym ludzi rozdzielonych przez śmierć.

\section{e) Śmierć sprywatyzowana i ukryta}

Próby negacji śmierci pojawiały się już w XVIII wieku, bowiem pod wpływem idei oświecenia nastąpiła w Europie radykalna zmiana nastawienia do

\footnotetext{
37 Por. tamże, 457.

38 Por. Ph. Aries, Geschichte des Todes, dz. cyt., 521.
} 
końcowego etapu życia człowieka. Ponieważ pojawił się lęk przed umieraniem, dlatego zaczęto eliminować z otoczenia ludzkiego wszystko, cokolwiek mogłoby przypominać o śmierci. Najpierw zaczęto usuwać cmentarze poza obręb ludzkich osiedli. Chociaż powodem zasadniczym tych decyzji były racje natury higienicznej, to jednak chodziło też w nich o to, aby miejsca pochówku zmarłych nie przypominały żyjącym o śmierci i umieraniu. Zalecano więc, aby otaczać cmentarze wysokim murem, a w roku 1936 rządząca we Francji koalicja socjalistów i komunistów nakazała ukryć mury cmentarne za drzewami i krzewami stale zielonymi. Aby uchronić ludzi przed przygnębiającym widokiem cmentarza, zaczęto starannie je maskowaćs ${ }^{39}$. Chociaż niektóre z tych decyzji były podyktowane medycznymi wymogami, trudno jednak oprzeć się wrażeniu, że usuwanie znaków przypominających o śmierci podyktowane było negatywnym nastawieniem ówczesnych społeczeństw do wszelkiej myśli o przemijaniu. Domagała się tego kultura i struktura społeczna młodego, agresywnego kapitalizmu. Bowiem ustanowiony przez niego ład społeczny, wysoki status i dynamizm organizatorów przemysłu mógł być psychologicznie osłabiony przez przypominanie im o skończoności ludzkiego losu. Dlatego też śmierć i wszelkie jej atrybuty zostały wyeliminowane z języka, kultury i otoczenia. Śmierć stała się tabu, o którym nie należało wspominać ${ }^{40}$. Ta praktyka w wieku XIX przybrała postać usłużnego kłamstwa, którym zapewniano chorego, że śmierć mu nie grozi. Kłamstwo to chroniło umierającego od niepokoju, rodzinę zaś przed rozmową z umierającym na temat śmierci ${ }^{41}$. Ważną rolę w tej sztuce okłamywania się pełniła „medykalizacja” umierania polegająca na tym, że pacjent i rodzina koncentrują się na diagnozie lekarskiej i sposobach zwalczania choroby aż do śmierci chorego.

Ta tendencja ukrywania umierania i śmierci utrzymała się w wieku XX, a nawet jeszcze wzrosła. Śmierć bowiem zaczęto postrzegać jako zjawisko nieestetyczne, cuchnące, a nawet brudne. Dlatego też chorych zaczęto ukrywać w szpitalach, aby tam mogli oni umierać. $Z$ biegiem czasu miejscem umierania stały się oddziały dla terminalnie chorych oraz hospicja. Złożyło się na to kilka czynników:

- Postęp medycyny, która wydaje się wszechmocna. Jeżeli stan chorego się pogorszy, trzeba wieźć go do szpitala mimo, że jego śmierć jest nieunikniona.

- Umierający jest czynnikiem zaburzającym codzienność. Utrudnia on pracę i prywatne życie innym, staje się uciążliwy. Organizacja dnia codziennego wyklucza opiekowanie się chorym i umierającym.

- Umierający nie pasuje do sterylnej atmosfery współczesnego świata. Zamiast śmierci w zaciszu domowym - umieranie w wykafelkowanym pomieszczeniu szpitalnym.

\footnotetext{
39 Por. V. Messori, Wyzwanie wobec śmierci, Kraków 1995, 94n.

40 Por. M. Mischke, Der Umgang mit dem Tod, dz. cyt., 112.

${ }^{41}$ Por. Ph. Aries, Geschichte des Todes, dz. cyt., 719.
} 
- Opieka nad umierającym jest fizycznym i psychicznym obciążeniem. Śmierć przestała być bowiem integralnym i zrozumiałym elementem współczesnego świata.

- Długotrwałość choroby poprzedzającej śmierć, która najczęściej związana jest $\mathrm{z}$ wiekiem ${ }^{42}$.

Niechętne nastawienie do śmierci i umierania trwało w społeczeństwach zachodnich do połowy XX wieku. Jeszcze we roku 1965 lekarz Elizabeth KüblerRoss napotkała na opór władz szpitalnych, gdy z inspiracji studentów teologii chciała przeprowadzić wywiady z umierającymi. Administracja szpitalna uważała, że w dobrze zorganizowanej placówce leczniczej nie powinno być osób zagrożonych bezpośrednią śmiercią. Śmierć bowiem jest konsekwencją źle działających instytucji powołanych do zwalczania choroby ${ }^{43}$.

$\mathrm{Ph}$. Ariès współcześnie dostrzega dwie rysujące się tendencje wobec śmierci. Jedna zawiera $w$ sobie powszechne wyznanie niemocy. Ponieważ nie ma możliwości wymknięcia się śmierci, dlatego lepiej o niej nie mówić. Śmierci jawi się jako absurd, wskazuje na bezsens życia ${ }^{44}$. Druga tendencja polega na podejmowaniu prób, aby śmierć sprowadzić z emigracji i humanizować ją. Wielką zasługę w zmianie nastawienia do śmierci ma wspomniana już E. Kübler-Ross. Opublikowana przez nią w roku 1969 książka Rozmowy o śmierci i umieraniu została sprzedana w USA i Anglii w liczbie ponad miliona egzemplarzy. Los ludzi umierających w samotności, pozbawionych godności i zainteresowania środowiska medycznego przyciągał uwagę opinii publicznej ${ }^{45}$.

Opisywana przez Ariès’a medykalizacja, skoszarowanie i prywatyzacja, a wreszcie depersonalizacja śmierci często jest określana w interdyscyplinarnych dyskusjach terminem zaczerpniętym z psychoanalizy: wyparcie do podświadomości. Dlatego wiele zagadnień związanych z postawami wobec śmierci ujmowane jest jako powrót wypartego, które przecież nie może być długo traktowane jako nieobecne.

42 Por. tamże, 223n.

43 Por. E. KüBler-Ross, Rozmowy o umieraniu i śmierci, Media Rodzina, Poznań 1998², 40.

44 Por. U.H.J. Körtner, Bedenken, dass wir sterben müssen, dz. cyt., 18.

45 Por. Ph. Aries, Śmierć odwrócona, w: Antropologia śmierci. Myśl francuska, PWN, Warszawa 1993, 266. 


\section{Historical and contemporary attitudes to death}

\section{SUMMARY}

Though death is a universal and real event, large diversity of the attitudes to death are observed. Depending on the culture and historical period, death has been perceivable as distant and horrible, or mysterious and fascinating. In the last years in the area of western civilization the increased interest in this issue occurred. Attempt has been made to consider death as one of the events of human life, which is present in both individual and social consciousness. Relegation of tanatological issues into subconsciousness or passing them over does not eliminate the confrontation with this important existential problem. The analysis of historical attitudes to death can help to avoid in our time mistakes, which in the past were making most often.

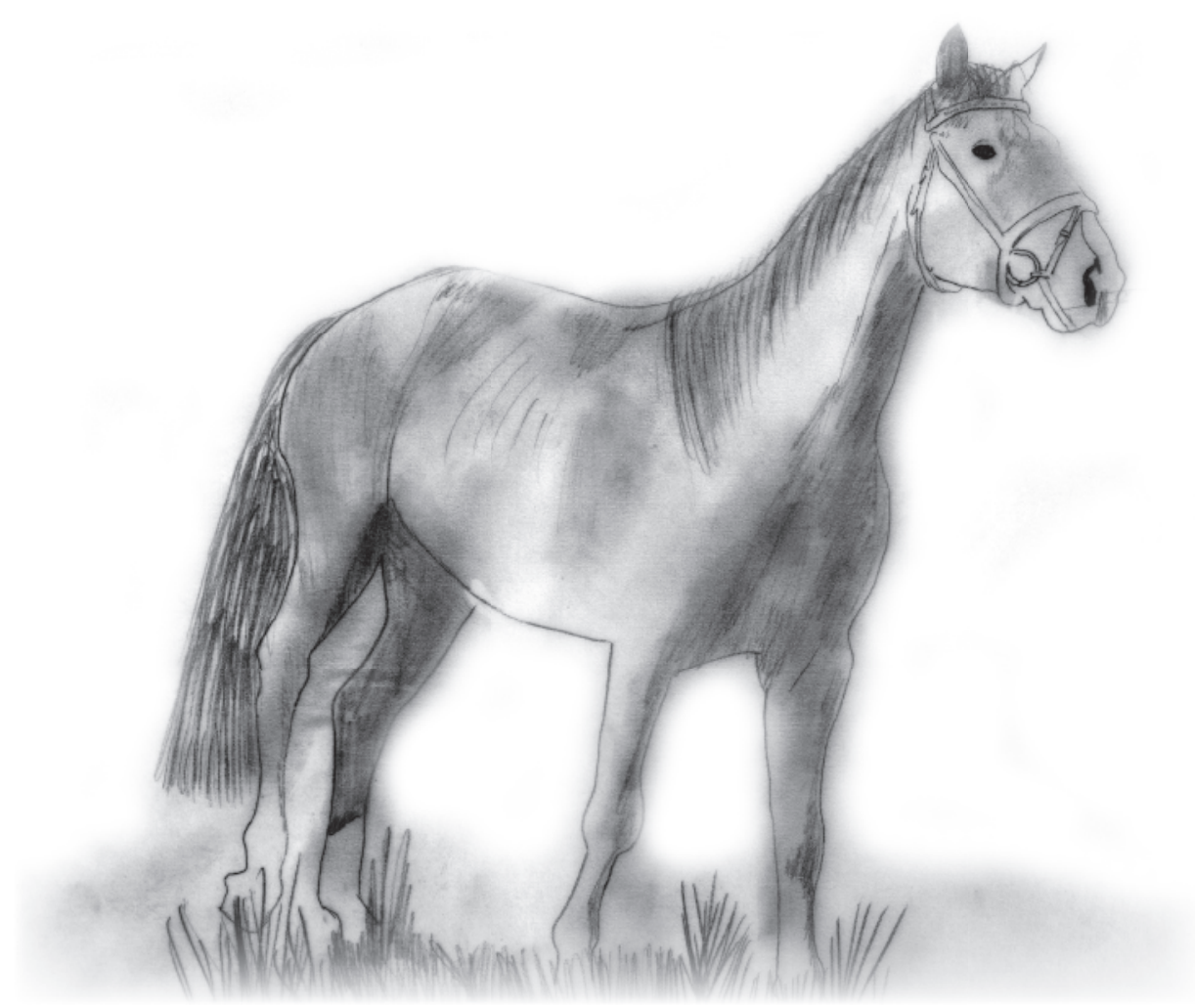

Rys. P. Piotrowski 